\title{
Studi Pendahuluan Keanekaragaman Genetik Kelapa Sawit Asal Kamerun di PT. Binasawit Makmur
}

\author{
Genetic Diversity Preliminary Study of Cameroon Origin Oil Palm \\ at PT. Binasawit Makmur
}

\author{
Upit Sarimana $^{1 *)}$, Nurcahyono Indarto ${ }^{1}$, Javier Herrero ${ }^{2}$, Pratiwi Erika ${ }^{1}$, Fahmi Wendra $^{1}$, \\ Zulhermana Zulhermana ${ }^{1}$, Dwi Asmono ${ }^{1}$ \\ ${ }^{1}$ Department Research \& Development, PT. Sampoerna Agro Tbk, Palembang 30127 \\ ${ }^{2}$ NEIKER Technalia, Granja Modelo Crta. Nac. 1, 01192, Arkaute-Vitoria (Alava), Spain \\ ${ }^{*}$ Penulis untuk korespondensi: upit.sarimana@sampoernaagro.com
}

(diterima 2 Mei 2019, disetujui 12 Juli 2019)

Sitasi: Sarimana U, Indarto N, Herrero J, Erika P, Wendra F, Zulhermana Z, Asmono D. 2019. Genetic diversity preliminary study of cameroon origin oil palm at PT. Binasawit Makmur. Jurnal Lahan Suboptimal: Journal of Suboptimal Lands. 8(2): 126-133.

\begin{abstract}
A plant breeding program needs genetic diversity information of germplasm, but the source of genetic diversity of oil palm plants in Indonesia is very narrow. In order to increase genetic diversity, the introduction of germplasm from Cameroon was conducted. The purpose of this study was to obtain a useful molecular marker in order to get genetic diversity information in Elaeis guinensis germplasm materials from Cameroon at PT. Binasawit Makmur (BSM). This preliminary research has been done in 2013. In this study, 300 samples of Cameroon oil palm DNA from 99 accessions and 10 samples DNA BSM material were analyzed by 9 microsatellite markers (simple sequence repeat; SSR). The 9 SSR markers used were very informative and we obtained 93 alleles with an average of 10.33 alleles per locus. The value of polymorphism information content (PIC) was around 0.746-0.889. The total genetic diversity was relative high $\left(\mathrm{H}_{\mathrm{T}}=0.814\right)$. The coordinate analysis showed no groups in both 99 accessions and BSM material. Based on phylogenetic analysis, 9 SSR markers could show the genetic diversity between the populations. To validate this fact, it needs further research using more molecular markers and samples.
\end{abstract}

Keywords: elaeis guinensis, genetic diversity, microsatellite markers

\begin{abstract}
ABSTRAK
Program pemulian tanaman sangat membutuhkan informasi tentang keragaman genetik plasma nutfah, akan tetapi diversitas genetik tanaman kelapa sawit di Indonesia sangat rendah. Guna meningkatkan keragaman genetik, dilakukan introduksi plasma nutfah dari Kamerun. Penelitian ini bertujuan untuk mendapatkan informasi penanda molekuler yang berguna untuk memperoleh informasi keragaman genetik dalam bahan tanam plasma nutfah Elaeis guinensis dari Kamerun di PT. Binasawit Makmur (BSM). Penelitian pendahuluan ini telah dilakukan pada tahun 2013. Dalam penelitian ini sebanyak 300 sample DNA kelapa sawit asal Kamerun dari 99 aksesi dan 10 sample DNA BSM material dianalisis dengan 9 penanda mikrosatelit (simple sequence repeat; SSR). Sembilan marka SSR yang digunakan sangat informatif dan menghasilkan 93 alel dengan rata-rata 10.33
\end{abstract}


alel per lokus. Nilai polimorfism information content (PIC) berkisar antara $0.746-0.899$. Total deversitas genetik cukup tinggi, yaitu $\mathrm{H}_{\mathrm{T}}=0.814$. Analisis koordinat menunjukkan bahwa ke 99 aksesi tidak mengelompok berdasarkan wilayah begitu juga material BSM. Dalam analisa filogenetik, 9 penanda SSR dapat menunjukkan keragaman genetik diantara populasi. Untuk membuktikan hal tersebut masih dibutuhkan penelitian lebih lanjut dengan menggunakan lebih banyak penanda molekuler.

Kata kunci: elaeis guinensis, keragaman genetik, marka mikrosatelit

\section{PENDAHULUAN}

PT Binasawit Makmur (BSM) sebagai salah satu perusahaan produsen benih kelapa sawit komersial di Indonesia selalu berupaya memenuhi kebutuhan bahan tanaman unggul kelapa sawit. Dengan pengembangan program pemulian yang dilaksanakan berkelanjutan, konsisten dan terarah diharapkan dapat menghasilkan benih kelapa sawit yang lebih baik lagi. Namun sempitnya keragaman genetik yang ada di BSM bahkan di Indonesia, menghambat program pemulian dan perakitan varietas baru. Hal ini ditegaskan oleh McCouch (2004) bahwa keragaman genetik yang tinggi merupakan kunci dasar pemuliaan tanaman. Keadaan ini mendorong pemulia mempelajari dan mencari sumber daya genetik kelapa sawit yang ada untuk meningkatkan variabilitas genetik. Seperti diketahui bahwa populasi plasma nutfah kelapa sawit banyak terdapat di Afrika Tengah dan Afrika Barat. Dengan demikian eksplorasi dan introduksi dari kedua wilayah tersebut dapat memberikan variasi yang lebih beragam pada plasma nutfah kelapa sawit Indonesia.

Kamerun dipilih sebagai tempat pelaksanaan eksplorasi diantaranya didasarkan pada alasan bahwa tanaman asal Kamerun masih jarang digunakan di Indonesia (Direktorat Perbenihan dan Sarana Produksi, Direktorat Jenderal Perkebunan, 2008). Melalui kolaborasi yang baik antar produsen benih (selanjutnya disebut konsorsium) dengan didukung oleh Dewan Minyak Sawit Indonesia dan Direktorat Jenderal Perkebunan, serta berkerja sama dengan IRAD La Dibamba, Kamerun, eksplorasi dan introduksi plasma nutfah kelapa sawit Kamerun telah dilakukan pada Mei 2008. Dari total 99 aksesi yang berhasil diintroduksi, 89 diantaranya berupa material dura dan 14 aksesi lainnya berupa material tenera. Setiap lokasi diambil tandan sebagai populasi, biji dari satu tandan dikumpulkan dan karakterisasi berdasarkan penotipe. Data yang lengkap mengenai karakter tersebut diperlukan dalam program persilangan, untuk pemilihan pokok yang akan dijadikan tetua. Begitu pula dengan karakter pertumbuhan dan produksi pokok, namun proses ini bisa memakan waktu 8 sampai 10 tahun. Sehingga untuk menghemat waktu dan dengan adanya perkembangan teknologi saat ini memungkinkan untuk mengetahui keragaman plasma nutfah spesifik dengan menggunakan penanda molekuler. Teknologi ini dapat membantu dalam program pemuliaan tanaman memberikan informasi struktur genetik suatu populasi (Barcelos et al., 2002), Sehingga informasi tersebut dapat digunakan untuk pemanfaatan sumber daya genetik yang lebih efektif dan efisien juga untuk pengembangan konservasi ex-situ plasma nutfah di masa yang akan datang (Hayati, et al., 2004)

Hingga saat ini penanda molekuler sudah banyak digunakan untuk mengevaluasi sumber daya genetik Keanekaragaman genetik E. Guineensis terutama pada material Kamerun. Penanda molekuler Microsatellites memiliki kelebihan polimorfis yang tinggi, dan dapat digunakan untuk analisis berbagai jaringan (Kalia et al., 2011). Beberapa journal microsatellites yang dapat dijadikan acuan pada tanaman kelapa sawit antara lain seperti (Billotte et al., 2005; Arias et al., 2013; Bakoumé et al., 2007; Singh et al., 2007; Cochard et al., 
2009; Zhou et al., 2015), juga pada beberapa tanaman lain seperti kakao (Kurniasih et al., 2011), kentang (Favoretto et al., 2011), gandum (Kumar et al., 2016) dan masih banyak lagi lainnya. Tujuan penelitian ini adalah untuk mendapatkan informasi keragaman genetik antara Elaeis guinensis hasil introduksi Kamerun dengan material yang ada di BSM dengan menggunakan penanda molekuler mikrosatelit.

\section{BAHAN DAN METODE}

\section{Bahan Tanam}

Material genetik yang digunakan dalam penelitian ini adalah pokok koleksi yang ditanam ex-situ pada tahun 2010 di Kebun Mesuji, Sumatera Selatan dengan luas areal 23,6 ha dan total 3017 pokok. Pokok-pokok ini merupakan hasil dari eksplorasi di Kamerun (Centre, East, Littoral, Northwest, South, Southwest, West). Lokasi sampling dicatat masing-masing berdasarkan Global Positioning System dengan variasi ketinggian antara 9-1326 m dpl (Gambar 1 peta lokasi sampling) dan jumlah pokok yang digunakan (Tabel 1) jumlah pokok dari tiap aksesi. Dari total 3017 pokok ini, kemudian dipilih 300 pokok yang digunakan dalam preliminary study ini. Pemilihan sample ini diambil secara acak mewakili ke 99 aksesi yang ada.

Tabel 1. Jumlah aksesi dan jumlah pokok yang digunakan sebagai sample pada tiap wilayah

\begin{tabular}{lcc}
\hline Wilayah Geografi & Jumlah Aksesi & Jumlah Pokok \\
\hline East & 35 & 104 \\
Center & 20 & 60 \\
West & 16 & 45 \\
North West & 11 & 12 \\
South West & 2 & 37 \\
Littoral & 11 & 9 \\
South & 4 & 33 \\
\hline Total & & 300 \\
\hline
\end{tabular}

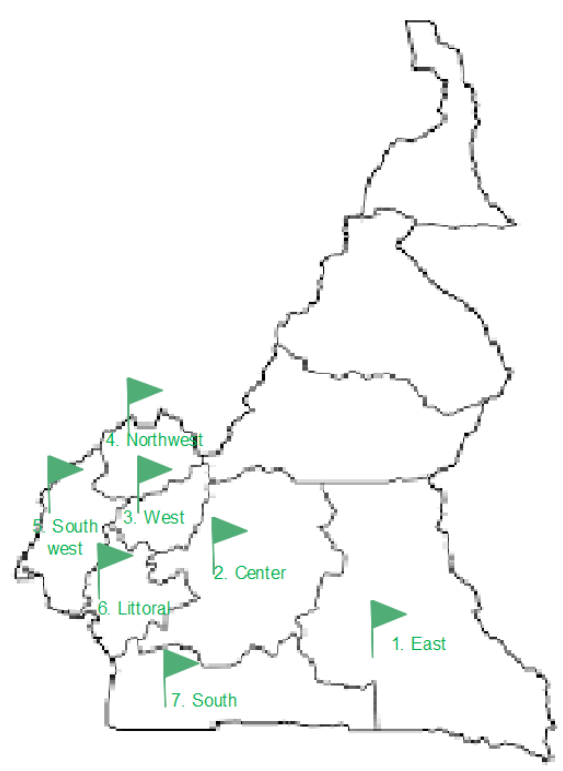

Gambar 1. Peta lokasi sampling E. guineensis material Kamerun 1. East, 2. Center, 3. West, 4. North West, 5. South West, 6. Littoral, 7. South

\section{Analisis Molekuler}

\section{Ekstraksi DNA dan Prosedur RRS}

Daun tombak dari tiap pokok di ekstrak DNA nya menggunakan Qiagen extraction kit (ref: 69104) mengikuti protokol manufacturer's dengan modification metode CTAB dan kualitas DNA di quantifikasi dengan menggunakan 
BioDrops spektrofotometer dan dianalisa pada gel agarose $0.8 \%$.

Sembilan marka mikrosatelit (Billotte et al. 2005) dengan tingkat polimorfisme yang tinggi digunakan dalam penelitian ini (Tabel 2). Amplifikasi dilakukan dalam campuran reaksi $25 \mu \mathrm{L}$ mengikuti protokol campuran master Promega GoTaq Green (ref: M7122) dengan modifikasi $10 \mu \mathrm{g}$ DNA. Produk PCR dielektroforesis dengan gel akrilamida $8 \%$, dan divisualisasikan menggunakan GelRed (Biotium) serta Dokumentasi Gel (BioRad). Hasilnya dicetak secara manual terhadap penanda ukuran molekul standar (Gambar 2).

\section{Analisis Data}

Hasil amplifikasi dari lokus-lokus mikrosatelit diskore dengan diklasifikasikan ke 1 (ada) atau 0 (tidak ada) dalam rentang yang dapat dibaca antara 50 dan 1000 bp (Gambar 4). Data Molecular analysis of variance (AMOVA) dihitung untuk mengetahui struktur, clustering dari individual, populasi dan pulau (Nei 1977). Koefisien korelasi dan signifikansi secara statistic (999 permutations untuk $\alpha=0.05$ ) dianalisis dengan menggunakan software GenAlex (Peakall \& Smouse 2012). Topologi analisis dilakukan dengan menggunakan metode neighbour-joining clustering dengan 100 bootstrap replika dan Unweighted Pair-Group Method Arithmetic Average (UPGMA), menggunakan Sequential Agglomerative Hierarchical Nested Cluster Analysis (SAHN-clustering) dan TREE program from NTSYS-pc, version 2.02 packages (Rohlf 1998) dan DARwin 6 (Soft ware developed by CIRAD berdasarkan Dice index (Nei 1983)

Tabel 2. Daftar marka yang digunakan dalam penelitian ini

\begin{tabular}{llrr}
\hline Kode Marker & \multicolumn{1}{c}{ Repeat motif } & \multicolumn{2}{c}{ Sequence 3' - '5 } \\
\hline mEgCIR1713 & (GTAT)3(GT)12 & GCTGAAGATGAAATTGATGTA & TTCAGGTCCACTTTCATTTA \\
mEgCIR3544 & (GA)14 & AGCAGGGCAAGAGCAATACT & TTCAGCAGCAGGAAACATC \\
mEgCIR3275 & (GA)17 & GAAGCCTGAGACCGCATAGA & TTCGGTGATGAAGATTGAAG \\
mEgCIR3376 & (GA)19 & CCCTCCCTGCTACCTTCT & TTATGTGAGTGCCTTTGATG \\
mEgCIR3400 & (GA)18 & CAATTCCAGCGTCACTATAG & AGTGGCAGTGGAAAAACAGT \\
mEgCIR2569 & (GA)16 & TAGCCGCACTCCCACGAAGC & CCAGAATCATCAGACTCGGACAG \\
mEgCIR0037 & (GA)17 & CCAGTCTGCTAACCATCCTATAC & TCTCACTTCCTCCCCACATC \\
mEgCIR0782 & (GA)20 & CGTTCATCCCACCACCTTTC & GCTGCGAGGCCACTGATAC \\
mEgCIR3281 & (GA)17 & TTTCTTATGGCAATCACACG & GGAGGGCAGGAACAAAAAGT \\
\hline
\end{tabular}

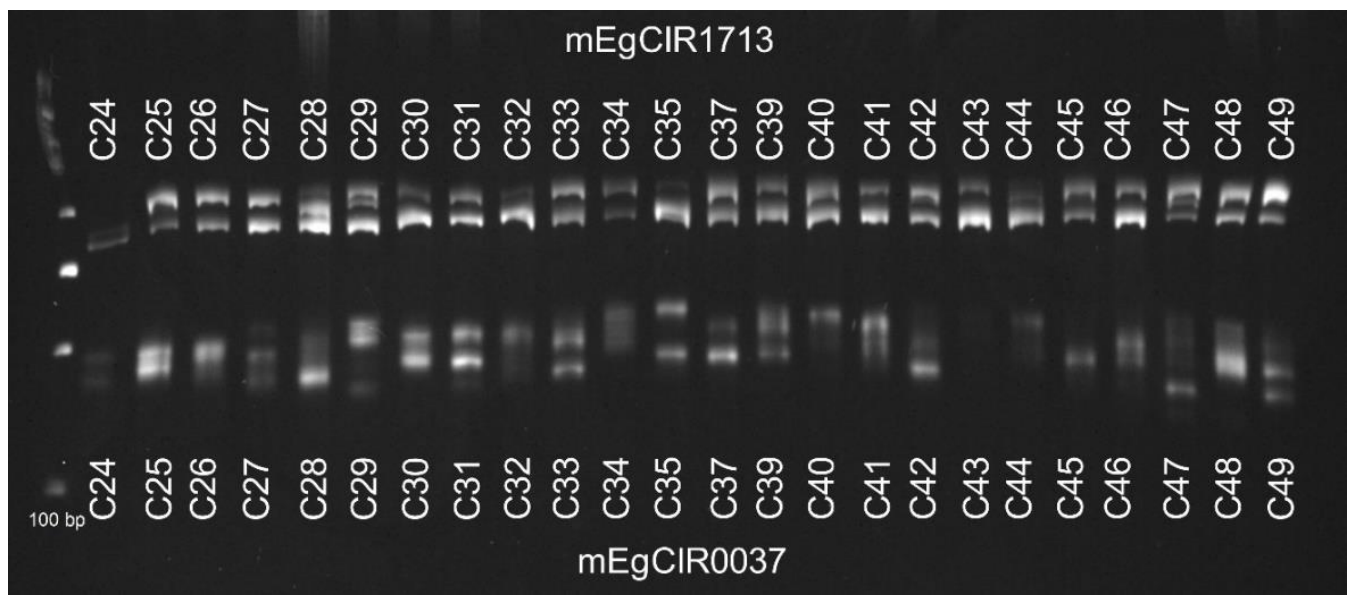

Gambar 2. Hasil visualisasi marker mEgCIR1713 dan mEgCIR0037 


\section{HASIL DAN PEMBAHASAN}

Semua marka yang digunakan sangat polimorfis dengan total 93 alel, jumlah alel per lokus berkisar antara 9 sampai 12 (Tabel 3). Rata-rata jumlah alel per marka 10.33 tersebut tidak sejalan dengan (Tasma et al., 2013) yang hanya 3,6 alel per marka SSR. Expected heterozygosity (Hexp) tinggi yaitu 0.566-0.804. Kesembilan marker yang digunakan menghasilkan PIC maximum analisis menunjukkan 0.889 mEgCIR3275 dan minimum adalah 0.746 mEgCIR3281 dengan nilai rata-rata 0,824. Range nilai tersebut lebih sempit dibandingkan (Tasma \& Arumsari 2013) dengan nilai PIC 0,63-0,91 dengan menggunakan 20 marka. Nilai PIC yang diperoleh pada studi awal ini juga tidak sejalan dengan c hanya berkisar 20\%-73\% meskipun telah mengunakan 12 marka.

Untuk mengetahui keragaman genetik material dapat dilihat pada Tabel 4. Sedangkan pada Tabel 5 hasil analisa AMOVA, dimana variasi yang paling tinggi terjadi antar dan dalam individu masingmasing 36\% serta 59\%. Hal ini terjadi karena persilangan terbuka di alam. Variasi dalam populasi rendah hanya $1 \%$ (Table 5). Analisa clustering neighbor-joining tetap dapat dilakukan dengan analisa DARwin, meskipun tidak dapat dilihat jelas pengelompokan antar aksesi mapun wilayah (Gambar 3). Analisis koordinat menunjukkan bahwa semua aksesi tidak mengelompok berdasarkan wilayah (Gambar 4).

Tabel 3. Keragaman genetik untuk setiap lokus

\begin{tabular}{lcccc}
\hline Lokus & PIC & Hexp & Hobs & Jumlah Alel \\
\hline mEgCIR1713 & 0,79 & 0,817 & 0,566 & 8 \\
mEgCIR3544 & 0,81 & 0,833 & 0,488 & 10 \\
mEgCIR3275 & 0,889 & 0,899 & 0,623 & 14 \\
mEgCIR3376 & 0,806 & 0,829 & 0,414 & 10 \\
mEgCIR3400 & 0,875 & 0,887 & 0,599 & 12 \\
mEgCIR2569 & 0,857 & 0,872 & 0,515 & 11 \\
mEgCIR0037 & 0,747 & 0,781 & 0,414 & 7 \\
mEgCIR0782 & 0,879 & 0,891 & 0,596 & 12 \\
mEgCIR3281 & 0,746 & 0,779 & 0,316 & 9 \\
\hline \multicolumn{1}{c}{ Total } & & & & 93
\end{tabular}

Keterangan: Jumlah alel per lokus, Hobs: Nilai observasi heterozigositas, Hexp: Nilai ekspektasi heterozigositas, PIC: Polymorphic Information Content

Tabel 4. Keragaman dan koefisien diferensiasi genetik serta F-statistic

\begin{tabular}{lllllllll}
\hline $\mathrm{N}$ & Ho & Hs & Ht & Dst & Gst & Gis & Nm & Fst \\
\hline 300 & 0.506 & 0.736 & 0.814 & 0.341 & 0.063 & 0.03 & 0.37 & 0.096 \\
\hline
\end{tabular}

\section{Keterangan:}

Ho: rata-rata observed genetic diversity;

Hs: rata-rata keragaman genetik antar group

HT: keragaman genetik total

DST: rata-rata keragaman genetik antar subgroups

GST: koefisien genetik diferensiasi

GIS: koefisien endogamy

FST: total differentiation of genetic diversity 
Tabel 5. Hasil AMOVA

\begin{tabular}{lrrrrr}
\hline Sumber Keragaman & \multicolumn{1}{c}{ df } & \multicolumn{1}{c}{ SS } & \multicolumn{1}{c}{ MS } & Est. Var. & $\%$ \\
\hline Antar Populasi & 6 & 123.640 & 20.607 & 0.201 & $5 \%$ \\
Antar Individu & 290 & 1453.422 & 5.012 & 1.373 & $36 \%$ \\
Intra Individu & 297 & 673.000 & 2.266 & 2.266 & $59 \%$ \\
\hline Total & 593 & 2250.062 & & 3.840 & $100 \%$ \\
\hline
\end{tabular}

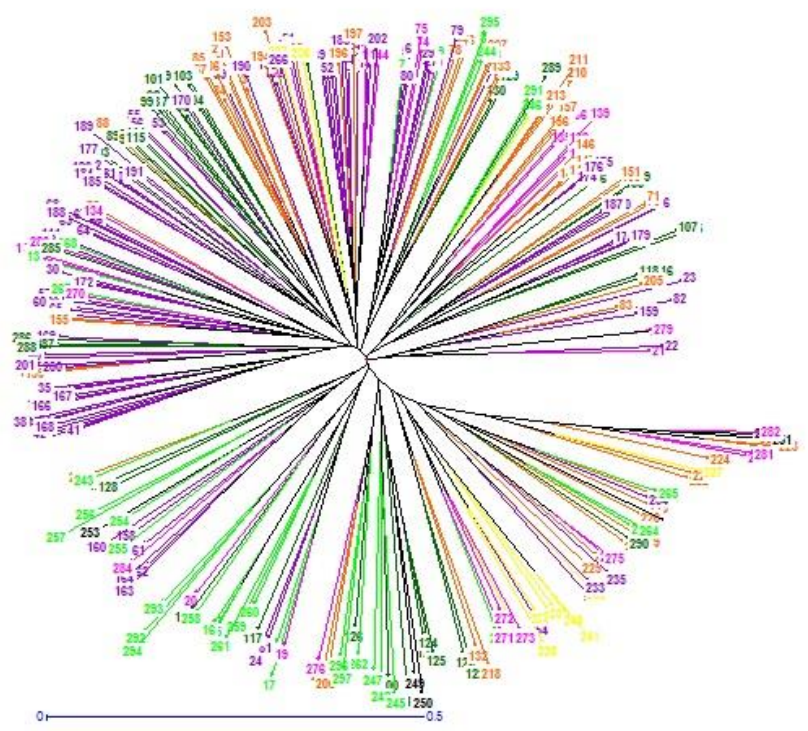

Gambar 3. Topologi berdasarkan metode clustering neighbor-joining dan indeks dissimilarity aksesi kelapa sawit dari kamerun dan BSM. Analisis berdasarkan 9 marka SSR dengan nilai bootstrap lebih besar dari 100

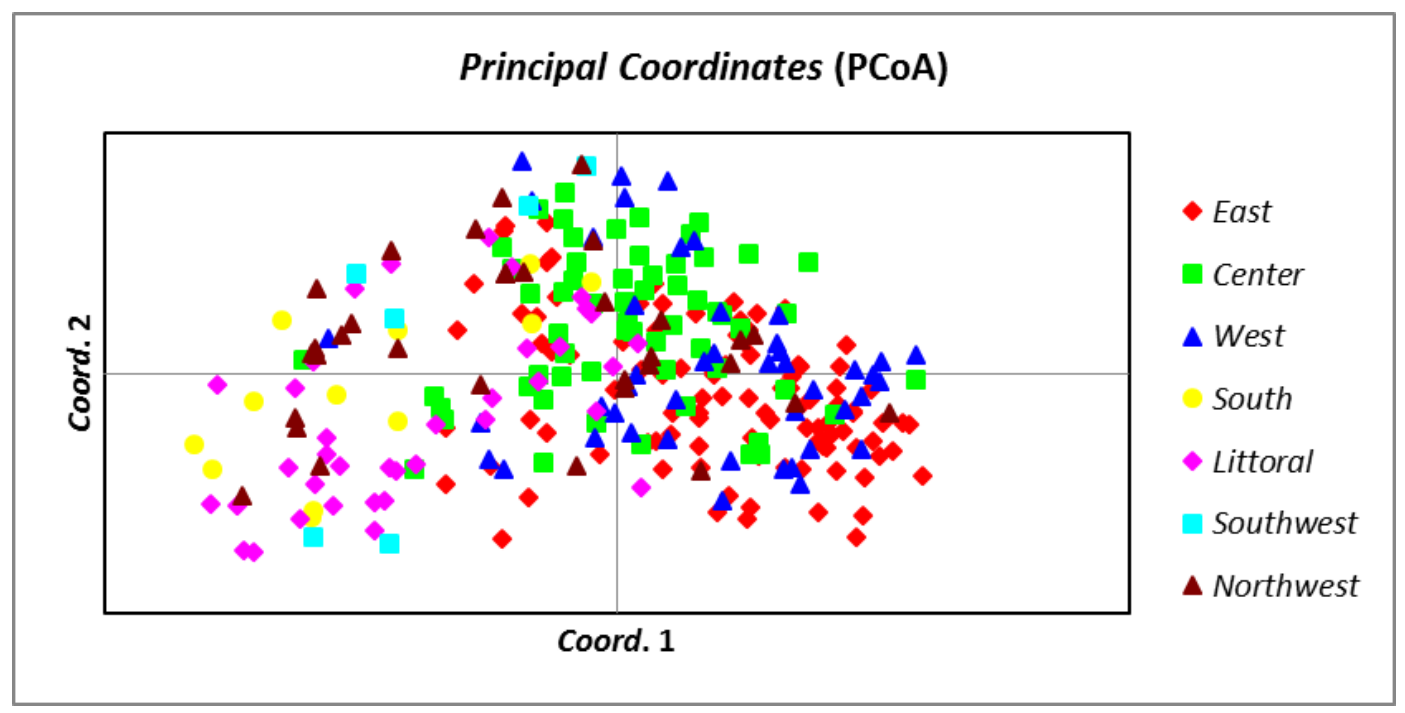

Gambar 4. Sebaran 300 kelapa sawit yang dikoleksi dari 7 wilayah Kamerun yang berbeda dengan menggunakan 9 mikrosatelite marka SSR. Setiap warna menunjukkan asal sample 
Dari hasil analisis data tersebut diketahui bahwa nilai He lebih tinggi jika dibandikan dengan $\mathrm{He}$ dari penelitian sebelumnya 0.625 - 0.669 (Arias et al. 2013). Namun nilai Hexp lebih besar dari Hobs yang berarti bahwa lokus tersebut memiliki tingkat heterozigositas yang rendah (Govindaraj et al. 2015).

Berbeda dengan level heterozigositas, level keragaman genetik antar wilayah cukup tinggi dapat dilihat dari nilai $\mathrm{Ho}, \mathrm{Hs}$ dan Ht. hal ini turut didukung dengan ratarata nilai PIC yang lebih dari $70 \%$ menunjukkan bahwa kesemua marker sangat informatif (Okoye et al. 2016). Sedangkan level perbedaan genetik antar asal sample rendah GST/FST. Hal ini berbeda dengan nilai aliran gen yang lebih besar dari $1(\mathrm{Nm})$ yang menandakan bahwa migrasi gen-gen dapat dengan mudah terjadi dan tidak ada batasan, namun polinasi akan tetap dibatasi oleh lokasi

\section{KESIMPULAN}

Dari hasil penelitian ini dapat disimpulkan bahwa marka SSR dapat digunakan untuk mempelajari keragaman genetik material yang berasal dari Kamerun. Marka tersebut juga dapat diaplikasikan ke 99 aksesi, namun untuk mempelajari lebih lanjut keragaman genetik material asal Kamerun membutuhkan lebih banyak marka lagi.

\section{UCAPAN TERIMA KASIH}

Penulis mengucapkan terima kasih kepada semua unit yang berperanserta dalam penelitian yaitu Departemen Riset dan Pengembangan, PT. Sampoerna Agro, Tbk.

\section{DAFTAR PUSTAKA}

Arias D, Montoya C, Romero H. 2013. Molecular characterization of oil palm Elaeis guineensis Jacq. materials from Cameroon. Plant Genetic Resources. 11(02):140-148.
Barcelos E, Amblard P, Berthaud J, Seguin M. 2002. Genetic diversity and relationship in American and African oil palm as revealed by RFLP and AFLP molecular markers. Pesq. Agropec. 37(1):1105-1114.

Bakoumé C, Wickneswari R, Rajanaidu N, Kushairi A, Amblard P, Billotte N. 2007. Allelic diversity of natural oil palm (Elaeis guineensis Jacq.) populations detected by microsatellite markers: implications for conservation. Plant Genetic Resources. 5(2):104-107.

Billotte N, Marseillac N, Risterucci AM, Adon B, Brottier P, Baurens FC, Singh $\mathrm{R}$, Herran A, Asmadi H, Billot C, Amblard P, Durand-Gasselin T, Courtois B, Asmono D, Cheah SC, Rohde W, Ritter E and Charrier A. 2005. Microsatellite-based high density linkage map in oil palm (Elaeis guineensis Jacq.). TAG. Theoretical and applied genetics. 110(4):754-65.

Cochard B, Adon B, Rekima S, Billotte N, De Chenon RD, Koutou A, Nouy B, Omoré A, Purba AR, Glazsmann JC, Noyer JL. 2009. Geographic and genetic structure of African oil palm diversity suggests new approaches to breeding. Tree Genetics and Genomes. 5(3):493504.

Direktorat Perbenihan dan Sarana Produksi, Direktorat Jenderal Perkebunan. 2008. Aksesi Kelapa Sawit Asal Kamerun akan Segera Diintroduksi ke Indonesia. 14 Juli 2008. http://ditjenbun.deptan.go.id.

Favoretto P, Veasey EA, Melo PCTde. 2011. Molecular characterization of potato cultivars using SSR markers. Horticultura Brasileira. 29(4):542-547.

Govindaraj M, Vetriventhan M, Srinivasan M. 2015. Importance of Genetic Diversity Assessment in Crop Plants and Its Recent Advances: An Overview of Its Analytical Perspectives. pp.1-13.

Hayati A, Wickneswari R, Maizura I, Rajanaidu N. 2003. Genetic Diversity of Oil Palm (Elaeis guineensis Jacq.) Germplasm Collections from Africa: Implication for Improvement and 
Conservation of Genetic Resources. Theor Appl Genet. 2004. 108: 12741284.

Kalia RK, Rai MK, Kalia S, Singh R, Dhawan AK. 2011. Microsatellite markers: an overview of the recent progress in plants, Euphytica. 177(3): 309-334.

Kumar P, Yadava RK, Sandeep K, Pritam K. 2016. Molecular diversity analysis in wheat genotypes using SSR markers. Electronic Journal of Plant Breeding. 7(2):464-468.

Kurniasih S, Rubiyo, Setiawan A, Purwantara A, Sudarsono. 2011. Analisis keragaman genetik plasma nutfah kakao (Theobrtoma cacao L.) Berdasarkan Marka SSR. Jurnal Littri. 17(4):156162.

McCouch S. 2004. Diversifying selection in plant breeding. PloS Biol. 2 (10): 347.

Nei M. 1977. F-statistics and analysis of gene diversity in subdivided populations. Human Heredity. 41:225-233.

Nei M. 1983. Estimation of fixation indices and gene diversities. Human Heredity. 47:253-259.

Okoye MN, Uguru MI, Bakoumé C, Singh R, Okwuagwu CO. 2016. Assessment of Genetic Diversity of NIFOR Oil Palm Main Breeding Parent Genotypes Using Microsatellite Markers. American Journal of Plant Sciences. 07(01): 218237.
Peakall R, Smouse PE. 2012. GenAlEx 6. 5: genetic analysis in Excel. Population genetic software for teaching and research-an update. 28(19): 2537-2539.

Rohlf FJ. 1998. NTSYSpc Numerical Taxonomy and Multivariate Analysis System.

Singh R, Nagappan J, Tan S, Panandam JM, Cheah S. 2007. Development of simple sequence repeat (SSR) markers for oil palm and their application in genetic mapping and fingerprinting of tissue culture clones. Asia Pacific Journal of Molecular Biology and Biotechnology. 15(3):121-131.

Tasma IM, Warsun A, Satywan D, Syafauddin dan Martono B. 2013. Analisis kekerabatan 50 aksesi kelapa sawit (Elaeis guineensis Jacq.) asal kamerun berdasarkan marka mikrosatelit. Jurnal AgroBiogen. 9(1):19-27.

Tasma IM, Arumsari S. 2013. Analisis diversitas genetik aksesi kelapa sawit $\mathrm{K}$ Amerun berdasarkan marka SSR. Jurnal Litri. 19(4):194-202.

Zhou LX et al. 2015. Analysis of genetic diversity and population structure of oil palm (Elaeis guineensis) from China and Malaysia based on species-specific simple sequence repeat markers. Genetics and Molecular Research. 14(4). 